\title{
The Impact of Season, Parity, and Volume of Colostrum on Holstein Dairy Cows Colostrum Composition
}

\author{
Soheila Zarei', Gholam Reza Ghorbani', Mohammad Khorvash'1, 0'Brien Martin², \\ Amir Hossein Mahdavi ${ }^{1}$, Ahmad Riasi ${ }^{1}$ \\ ${ }^{1}$ Department of Animal Sciences, College of Agriculture, Isfahan University of Technology, Isfahan, Iran \\ ${ }^{2}$ Department of Animal Science, Obihiro University of Agriculture and Veterinary Medicine, Obihiro, Japan \\ Email: s.zareie@ag.iut.ac.ir
}

How to cite this paper: Zarei, S., Ghorbani, G.R., Khorvash, M., Martin, O., Mahdavi, A.H. and Riasi, A. (2017) The Impact of Season, Parity, and Volume of Colostrum on Holstein Dairy Cows Colostrum Composition. Agricultural Sciences, 8, 572-581. https://doi.org/10.4236/as.2017.87043

Received: January 22, 2015

Accepted: July 22, 2017

Published: July 25, 2017

Copyright $\odot 2017$ by authors and Scientific Research Publishing Inc. This work is licensed under the Creative Commons Attribution International License (CC BY 4.0).

http://creativecommons.org/licenses/by/4.0/

c) (†) Open Access

\begin{abstract}
The objectives of the study were to assess colostrum quality and nutrients in dairy cows in Isfahan, Iran, and to determine the effects of calving season, parity, and volume of first colostrum on colostrum quality. Colostrum samples were collected over the period January-December, from 365 Holstein dairy cows from 12 dairy farms and analyzed for their IgG, IgM, total solids, fat, protein, lactose, $\mathrm{Ca}$, and $\mathrm{P}$ concentrations. The IgG and IgM contents were measured to be $35.8 \pm 17.6$ and $5.8 \pm 3.8 \mathrm{mg} / \mathrm{mL}$, respectively. Mean percentages of total solids, fat, protein, and lactose in the samples were $27.2 \pm 5.8,4.6$ $\pm 3.4,18.5 \pm 4.9$, and $2.0 \pm 0.9$, respectively while calcium and P concentrations were $2.69 \pm 0.9$ and $2.02 \pm 0.88 \mathrm{~g} / \mathrm{kg}$. Colostral IgG and IgM concentrations were found to be higher during the winter months. Calving season affected lactose, $\mathrm{Ca}$, and $\mathrm{P}$ concentrations as evidenced by the higher colostral lactose percentages in cows calved in the fall but higher calcium and $\mathrm{P}$ concentrations in those calved in the summer. Parity had no significant effects on IgG and IgM concentrations. However, a decreasing trend was observed in $\mathrm{Ca}$ and $\mathrm{P}$ concentrations with increasing parity. Volume of first milking colostrum did not have any effect on colostral composition. The findings of this study indicate that colostrum quality may be affected by calving season.
\end{abstract}

\section{Keywords}

Immunoglobulin, Colostrum, Parity, Season, Volume of Colostrum

\section{Introduction}

Sufficient colostrum can guarantee the supply of essential nutrients and immune 
factors required for the healthy growth of newborn calves after parturition. Fat and lactose in colostrum are utilized as a source of energy to help maintain the body temperature of neonate calves during their first days of life [1]. In addition to its nutritional value, an equally significant value of colostrum lies in its role in the development of passive immunity in calves by the three types of immunoglobulins (i.e., IgG, $\operatorname{IgM}$, and $\operatorname{IgA}$ ). Bovine IgM is an imperative component of colostrum for immune response and complement fixation while it also serves as an agglutinating antibody of the serum. The role of IgM is in fighting parasitic infections of plasma. IgG is the primary immunoglobulin for passive immunization of the newborn calf. Colostrum quality plays a vital role in the survival of newborn calves [2] but its quality varies among individual cows [3]. Colostrum quality is defined by Ig concentration, especially that of IgG.

Identification of the best quality colostrum has always been a major challenge to dairy farmers. Season of calving, parity, dry period length [4] [5], volume of colostrum [3] [5] [6] heat stress [7] [8] [9] and maternal feeding during the dry period [10] [4] [11] have been suggested to influence colostral composition. In a recent study by [5], samples of spring and fall colostrum were found to have the lowest and the highest levels of IgG, respectively. Some studies reported colostrum IgG content to increase with increasing parity [1] [4]. Moreover, [5] claimed that a relationship existed between IgG concentration and colostrum volume while [12] and [6] found no such relationship. Most previous reports on colostrum quality have concentrated on IgG as a main component of colostrum and parity or volume of colostrum, and occasionally season, as factors affecting colostrum IgG. Numerous studies have focused on colostrum quality, and a few studies based their investigation on the place of experiment to evaluate different breeds of dairy cows in terms of their colostrum Ig concentration. To the best of our knowledge, the likely association between most of the colostrum constituents (i.e., fat, protein, and lactose, $\mathrm{Ca}, \mathrm{P}$ ), on the one hand, and certain influential factors, on the other, has been rarely ever studied. Moreover, no study is reported to have considered in one single study the effects of different factors involved in the nutritional value and quality of colostrum on Holstein dairy cows as a dominant breed the world over. The objectives of the present study were: 1 ) to evaluate colostrum quality in terms of its Ig content and nutrients in Holstein dairy cows, and 2) to identify the association between colostrum quality and the three factors of calving season, dam parity, and volume of first milking colostrum.

\section{Materials and Methods}

\subsection{Collecting and Analyzing Samples}

For the purposes of the present study, 12 commercial dairy farms with intensive management were randomly selected from different locations in Isfahan, Iran. Herd sizes ranged from 300 to 3000 cows, which were grouped into 3 different herd sizes: small with $\leq 300$, medium with 300 to 1000 , and large with $\geq 1000$ cows. All the selected farms used either free stall housing or open pack. No spe- 
cific grazing program is practiced in Isfahan and cows are mostly fed hay and concentrate. Dry period in the selected farms lasts for approximately 50 to $60 \mathrm{~d}$ and cows are separated and placed in maternity pens around 15 to $10 \mathrm{~d}$ before calving.

In each season, the farmers were asked to collect 2 samples for parity (1st through 3 rd or more) which made eight samples per season per farm. Thus, a total of 365 samples of first milking colostrum were collected from cows calved during spring (April to June), summer (July to September), fall (October to December), and winter (January to March). Cows were milked within $4 \mathrm{~h}$ of calving before nursing the newborn. Colostrum samples were collected in three $50 \mathrm{~mL}$ bottles per cow and immediately frozen at $-4^{\circ} \mathrm{C}$. Cow parity, date of calving, volume of first milking colostrum and dry period length were recorded. The samples were then transferred to the laboratory on ice and stored at $-20^{\circ} \mathrm{C}$ until analysis. All blood-stained samples were discarded before analysis. Prior to analysis, all the samples were thawed at room temperature and then diluted (1:3, vol: vol) with a phosphate buffer solution ( $\mathrm{pH}$ 7.4) to reduce sample viscosity and prevent technical difficulties commonly encountered with highly viscous samples. The concentrations of IgG and IgM were determined by ELISA (kit E10-118 and 101, Bethyl Laboratories, Montgomery, TX, USA). Also, protein, fat, lactose, and total solids contents in diluted samples were determined using infrared (Milk-O-Scan133 B infra-analyzer, FØSS Electric, Denmark). Calcium and $\mathrm{P}$ concentrations were determined following the method described in [13] with the following modifications: one gram of colostrum was digested in nitric and percholoric acids (9:1) on a hot plate and the acid content was allowed to evaporate. After cooling, $10 \mathrm{~mL}$ of $1.0 \mathrm{~N} \mathrm{HCl}$ was added. Finally, Ca and P were analyzed by ELISA using the modified method [14].

\subsection{Statistical Analysis}

Normality was verified using the UNIVARIATE procedure. Data for IgG; IgM; percentages of fat, protein, lactose, and total solids; as well as $\mathrm{Ca}$ and $\mathrm{P}$ concentrations were analyzed using the GLM procedure by SAS 9.1 (SAS Institute, 2003) to determine the effects of season (winter, spring, summer, and fall), parity of dam ( 1 to $>3$ ), volume of first milking colostrum, and farm. The data thus obtained were reported as least squares means \pm standard error of the means (SEM). Effects were considered significant at $\mathrm{P}<0.05$ and trends at $\mathrm{P}<0.1$ [15].

\section{Results and Discussion}

\subsection{Colostrum Composition}

A total of 365 colostrum samples from Holstein cows were analyzed for the current study. Sample means for IgG, IgM, fat, protein, lactose, TS, Ca, and P are presented in Table 1. The industrial standard for colostrum is one with more than $50 \mathrm{mg}$ of IgG/ml. Based on the data obtained, only $18.3 \%$ of the samples collected had an IgG content $>50 \mathrm{mg} / \mathrm{ml}$, with a distribution in the range of 8.7 to $104.7 \mathrm{mg} / \mathrm{ml}$ and a mean value of $35.8 \pm 17.6 \mathrm{mg} / \mathrm{ml}$, indicating that the IgG 
Table 1. Colostrum composition from 365 Holstein cows raised on Isfahan dairy farms.

\begin{tabular}{ccccc}
\hline Factor & Mean & $\mathrm{SD}^{\mathrm{a}}$ & Min & Max \\
\hline Volume, L & 7.0 & 3.2 & 2.0 & 23 \\
IgG, mg/ml & 35.8 & 17.6 & 8.7 & 104.7 \\
IgM, mg/ml & 5.8 & 3.8 & 0.8 & 27.2 \\
Fat, \% & 4.6 & 3.4 & 0.3 & 20.9 \\
Protein, \% & 18.5 & 4.9 & 4.9 & 29.6 \\
Lactose, \% & 2.0 & 0.9 & 0.3 & 5.2 \\
Total solid, \% & 27.2 & 5.8 & 12.9 & 47.2 \\
Ca, mg/kg & 2691 & 900 & 914 & 8078 \\
P, mg/kg & 2023 & 878 & 609 & 7896 \\
\hline
\end{tabular}

a. SD: Standard Deviation.

mean was lower than those reported in other studies $(48.2 \mathrm{mg} / \mathrm{ml}$ in [3]; 40.9 $\mathrm{mg} / \mathrm{ml}$ in [16]; $68.8 \mathrm{mg} / \mathrm{ml}$ in [1]. Colostral IgM also varied greatly from 1 to $27.2 \mathrm{mg} / \mathrm{ml}$. IgM mean was $5.8 \pm 3.8 \mathrm{mg} / \mathrm{ml}$, which was greater than that reported by [15] but the same as the value reported by [17]. Fat concentration in the present study was found to be $4.6 \% \pm 3.4 \%$, with a range of $0.3 \%$ to $20.9 \%$. The mean value of fat content measured in all the samples was lower than those in previous reports [8] [16] [18]. The lactose content of the samples ranged from $0.3 \%$ to $5.2 \%$ with a mean value of $2.0 \% \pm 0.9 \%$ which is lower than the values reported in the literature [1] [16]. The reducing trend of lactose is in contrast to the increasing trend for other nutrients in colostrum. However, this proportion of colostrum nutrients is physiologically necessary for the neonate calf [1] [13]. Protein content was measured in the present study within the range of $4.6 \%$ to $29.6 \%$ with a mean value of $18.5 \% \pm 4.9 \%$, which was higher than those reported in recent studies (14.9\% in [17]; $12.5 \%$ in [1]. Total solids content was found to be $27.6 \% \pm 5.8 \%$, ranging from $12.9 \%$ to $47.2 \%$, which was consistent with the values reported by [16] but lower than the $22.2 \%$ total solids (TS) reported by [1]. Calcium and P concentrations were $2691 \pm 900$ and $2023 \pm 878 \mathrm{mg} / \mathrm{kg}$, respectively. Almost equal values were reported in [19] but [16] observed lower values. The level of dietary fat and protein during pregnancy did not affect colostrum nutrients [16]. It should be noted that the results obtained from colostrum composition analysis might have been affected by certain factors such as individuality among the cows and probably the lab instruments used.

\subsection{Season of Calving}

All the data on components of colostrum samples as influenced by season and parity are presented in Table 2 and Table 3, respectively. Our results indicate that season of calving has a significant effect $(P=0.0001)$ on IgG and IgM concentrations in colostrum. Significantly higher concentrations of IgG and IgM 
Table 2. Effect of season of calving on first milking colostrum composition from 365 Holstein cows on Isfahan dairy farms.

\begin{tabular}{cccccccccc}
\hline & \multicolumn{7}{c}{ Season of calving (number of samples) } \\
\cline { 2 - 8 } Factor & \multicolumn{7}{c}{ Spring (92) } & \multicolumn{7}{c}{ Summer (93) } & \multicolumn{2}{c}{ Fall (89) } & Winter (91) & \\
\cline { 2 - 8 } & LSM $^{1}$ & SEM $^{2}$ & LSM & SEM & LSM & SEM & LSM & SEM & \\
\hline Volume, L & 7.7 & & 7.1 & & 6.5 & & 6.8 & & \\
IgG, mg/ml & $23.3^{\mathrm{c}}$ & 1.52 & $41.2^{\mathrm{b}}$ & 1.49 & $23.8^{\mathrm{c}}$ & 1.81 & $50.8^{\mathrm{a}}$ & 1.57 & 0.001 \\
IgM, mg/ml & $6.1^{\mathrm{b}}$ & 0.36 & $5.4^{\mathrm{b}}$ & 0.44 & $2.97^{\mathrm{c}}$ & 0.37 & $8.4^{\mathrm{a}}$ & 0.38 & $<0.0001$ \\
Fat, \% & 4.2 & 0.3 & 4.8 & 0.4 & 4.6 & 0.3 & 4.6 & 0.3 & 0.15 \\
Protein, \% & 18.1 & 0.5 & 18.9 & 0.6 & 18.7 & 0.5 & 18.8 & 0.5 & 0.22 \\
Lactose, \% & $1.8^{\mathrm{b}}$ & 0.1 & $1.8^{\mathrm{b}}$ & 0.1 & $2.1^{\mathrm{a}}$ & 0.1 & $2.0^{\mathrm{ab}}$ & 0.1 & 0.05 \\
Total solid, \% & 27.9 & 0.6 & 27.2 & 0.6 & 28.4 & 0.7 & 27 & 0.6 & 0.06 \\
Ca, mg/kg & $2443^{\mathrm{b}}$ & 95.2 & $3086^{\mathrm{a}}$ & 109.2 & $2629^{\mathrm{b}}$ & 96.2 & $2694^{\mathrm{b}}$ & 100.2 & 0.0002 \\
P, mg/kg & $1906^{\mathrm{b}}$ & 78.8 & $2200^{\mathrm{a}}$ & 90.4 & $1833^{\mathrm{b}}$ & 79.7 & $1731^{\mathrm{b}}$ & 83.3 & 0.001 \\
\hline
\end{tabular}

1. LSM $=$ Least Squares Mean; 2. SEM $=$ Standard Error of the Mean. $a, b, c$. Means within the same row with different superscripts differ, $\mathrm{P}<0.05$.

Table 3. Effect of parity on first milking colostrum composition from 365 Holstein cows on Isfahan dairy farms.

\begin{tabular}{|c|c|c|c|c|c|c|c|c|c|}
\hline \multirow{3}{*}{ Factor } & \multicolumn{9}{|c|}{ Parity of dam (number of samples) } \\
\hline & \multicolumn{2}{|c|}{$1(90)$} & \multicolumn{2}{|c|}{$2(94)$} & \multicolumn{2}{|c|}{$3(89)$} & \multicolumn{2}{|c|}{$3+(92)$} & \multirow{2}{*}{ P-value } \\
\hline & $\operatorname{LSM}^{1}$ & $\mathrm{SEM}^{2}$ & LSM & SEM & LSM & SEM & LSM & SEM & \\
\hline Volume, L & 5.9 & & 7 & & 7.4 & & 7.1 & & \\
\hline $\mathrm{IgG}, \mathrm{mg} / \mathrm{ml}$ & 36.9 & 1.48 & 35.6 & 1.39 & 36.3 & 1.41 & 37.53 & 2.31 & $0.08^{\mathrm{NS} 3}$ \\
\hline IgM, mg/ml & 5.6 & 0.36 & 5.7 & 0.34 & 6.7 & 0.35 & 7.2 & 0.56 & $0.14^{\mathrm{NS}}$ \\
\hline Fat, \% & $6.7^{\mathrm{a}}$ & 0.36 & $4.03^{\mathrm{b}}$ & 0.32 & $4.1^{\mathrm{b}}$ & 0.34 & $3.87^{\mathrm{b}}$ & 0.31 & $<0.001$ \\
\hline Protein, \% & $18.5^{\mathrm{b}}$ & 0.53 & $17.2^{\mathrm{b}}$ & 0.49 & $18.48^{\mathrm{b}}$ & 0.51 & $19.25^{\mathrm{a}}$ & 0.47 & 0.04 \\
\hline Lactose, \% & $2.0^{\mathrm{ab}}$ & 0.1 & $2.2^{\mathrm{a}}$ & 0.09 & $1.9^{\mathrm{b}}$ & 0.09 & $1.84^{\mathrm{b}}$ & 0.08 & 0.02 \\
\hline Total solid, \% & $29.2^{\mathrm{a}}$ & 0.6 & $25.48^{\mathrm{c}}$ & 0.55 & $26.4^{\mathrm{c}}$ & 0.57 & $27.16^{\mathrm{b}}$ & 0.53 & 0.003 \\
\hline $\mathrm{Ca}, \mathrm{mg} / \mathrm{kg}$ & $3015^{\mathrm{a}}$ & 95 & $2493^{\mathrm{b}}$ & 86 & $2523^{\mathrm{b}}$ & 90 & $2610^{\mathrm{b}}$ & 83 & 0.001 \\
\hline $\mathrm{P}, \mathrm{mg} / \mathrm{kg}$ & $2146^{\mathrm{a}}$ & 94 & $1982^{\mathrm{b}}$ & 86 & $1921^{\mathrm{b}}$ & 89 & $1931^{\mathrm{b}}$ & 83 & 0.07 \\
\hline
\end{tabular}

1. Least Squares Mean; 2. Standard Error of the Mean; 3. Non-significant a, b, c. Means within the same row with different superscripts differ, $\mathrm{P}<0.05$.

were recorded in the winter. IgG content was lowest in the spring and fall, but this trend was not observed for IgM concentration which was not low in the spring. Recently, [20] have shown that the reduced blood IgG levels before parturition are related to IgG levels in colostrum and that this association does not exist between colostrum IgM and blood IgM concentrations before parturition. Colostral IgM concentration depends on the action of the immune cells in the udder. However, the differences between the IgG and IgM trends in different seasons might be related to differences in their secretion patterns [7]. Neverthe- 
less, some studies found no effect of calving season on IgG concentration [3] [8] [17]. This is while [8] reported higher quantities of IgG in the colostrum of dairy cows during the summer as compared to winter. In contrast to our results, [4] studying dairy animals in Norway reported the lowest level of IgG content in cows calving during the winter. They argued that changing from silage to fresh grass feeding during the late pregnancy period might have influenced the colostrum IgG content. The cows in the present experiment, however, did not receive fresh grass. Considering the findings of [16] [21] and [22] that colostrum composition was not affected by prepartum maternal feeding, we did not attempt to determine the relationship between colostrum composition and prepartum feeding factors. In a recent study, [5] found that colostrum from cows calving in the spring (April and May) contained the lowest IgG content whereas the colostrum from those calving in the fall had a high IgG concentration. The effects of health status and nutrition were claimed to be the main reasons for the low IgG levels in samples collected in April [5]. The authors of [5] believed that longer dry periods might have increased the body condition score (BCS) and, consequently, declined the function of the immune system. This is while no correlation was observed in the present study between dry period and IgG concentration. Stress is also included among the factors that suppress the immune system, which leads to increasing cases of disease. It is well known that the secretion of glucocorticoids due to stress in late pregnancy might be associated with the decreasing ability of the immune system to produce the required antibodies [22] [23] [24]. We hypothesize that one reason for the decreasing level of IgG in the spring and fall seasons is the stressful conditions, including weather conditions and the temperature, in which the cows spent their late pregnancy period.

Calving season did not affect colostrum fat, protein, or total solids. However, lactose content varied with calving season. Cows calving in the fall had higher lactose content than those calving in the spring or summer. Calcium and P concentrations were greatest in the summer. These findings are not in agreement with those reported by [8] who observed that cows calving in the fall had higher colostral protein content. These same authors also reported no relationship between colostral fat concentration and season of calving. However due to the complexity of colostrum composition and individual variation among dairy cows we could not find the clear reason for the fluctuation of these parameters.

\subsection{Parity of Dam}

It was found in the current study that no significant differences existed among the samples with respect to their $\operatorname{IgG}(\mathrm{P}=0.08)$ and IgM concentrations $(\mathrm{P}=$ 0.14 ) with increasing parity but that there was a trend of higher IgG and IgM concentrations with increasing parity (Table 3 ). The Previous studies had revealed an increasing trend for Ig content with increasing parity [1] [4]. Similarly, we observed a similar trend but no significant differences across parities. The results reported here are similar to those reported by [25] who reported no significant differences among parities with respect to colostrum IgG and IgM con- 
tents. However, these researchers observed differences among parities with respect to total Ig and observed that many of these differences were due to IgA content. Reference [26] found no differences among the first, second, and third parities. However, cows in their fourth to seventh parities exhibited higher colostrum IgG values. Cows in higher parities reportedly seem to produce colostrum with higher amounts of IgG probably due to their exposure to more antigens in their lifetime [16] [5]. This, however, does not agree with our findings. Nonetheless, our findings support the idea maintained by previous researchers that the colostrum of first parity cows should not be discarded [3] [20] [27].

Fat content measured in the present study was significantly higher in the first parity than in others, but the highest protein content was recorded with older cows (more than 3rd parity). The cows in their first, second, and third parities were not significantly different with respect to their colostrum protein content. Reference [1] found that protein content in colostrum samples collected from different breeds did not differ significantly across the parities. In our experiment, lactose percentage was observed to be significantly higher in the first and second parities. Likewise, total solids varied with parity given the significant correlation among fat, protein, and total solids. However, in a recent study, [1] reported that cows in their third lactation produced higher colostrum lactose contents. Moreover, [28] observed that colostral $\mathrm{Ca}$ and $\mathrm{P}$ concentrations were higher than those in milk, but quickly declining after $24 \mathrm{~h}$ postpartum. In the present study, primiparous cows had more colostral $\mathrm{Ca}$ and $\mathrm{P}$, which supports the results of [28] who reported that colostral $\mathrm{Ca}$ and $\mathrm{P}$ concentrations exhibited a decreasing trend with increasing parity by up to the third or even higher parities. These authors concluded that dairy cows need to consume more minerals at parturition as these minerals are transferred to colostrum. Parity of dam is the main reason for the high $\mathrm{Ca}$ and $\mathrm{P}$ concentrations in colostrum and their low quantities in plasma at parturition [28] [29].

\subsection{Volume of First Milking Colostrum and Farm}

Regarding volume of first milking colostrum in this study, it was found to influence neither colostrum quality nor its components $(P>0.05)$. In fact, no correlation could be established between volume of first milking colostrum and the parameters measured in this study. There are, however, controversial reports on the relationship between volume of first milking colostrum and colostrum quality so that some have reported an inverse relationship (e.g., [5] [6] while others have not (e.g., [12]). According to [30], higher milk volume may lead to the dilution of IgG in the udder, which could explain the negative correlation established by some researchers between IgG and volume of first milking colostrum.

Different levels of IgG and IgM were observed in samples collected from the different farms studied in this experiment; higher IgG levels were recorded for farms with a large herd size, but no differences were found among farms with respect to IgM or other measured parameters (Figure 1). Herd size may affect the management of farms, which thereby leads to different colostrum qualities 


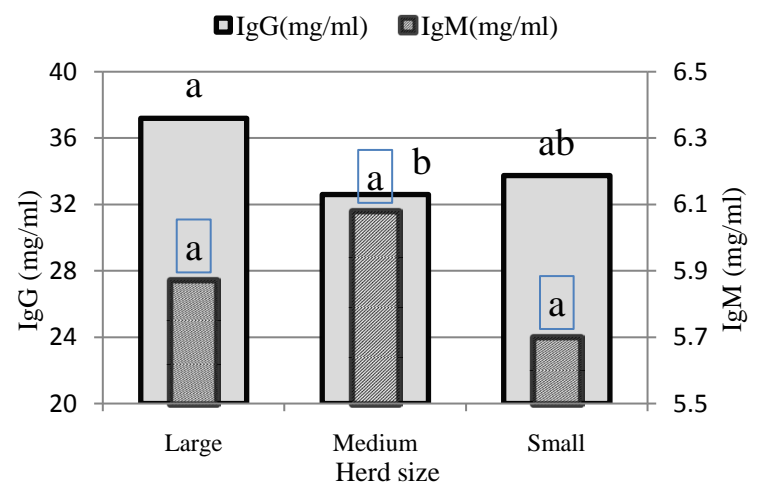

Figure 1. Immunoglobulin $\mathrm{G}$ and $\mathrm{M}(\mathrm{mg} / \mathrm{ml})$ in colostrum samples from 365 cows raised on different dairy farms in Isfahan, Iran, classified based on herd size.

[16]. The results obtained from this study indicate that farms with larger herds have been more successful in producing high quality colostrum than those with small or medium herd sizes.

\section{Conclusion}

In short, season of calving was found to have effects on colostrum quality so that the highest IgG and IgM concentrations were measured during the winter months. Regarding the effect of parity, no significant differences were observed in colostrum quality across the different parities as affected by the volume of first milking colostrum. The data obtained from this study suggest that season of calving may be one factor that could be exploited in identifying colostrum quality used for feeding newborn calves whereas parity and volume of first milking do not serve as reliable indicators of the expected colostrum quality.

\section{Acknowledgements}

Authors are thankful to the staff of the Dairy Research and Training Unit of Isfahan University of Technology (Isfahan, Iran) for their assistance. We also thank the farms including Goldasht Nemune, Golsharhr, Nasr, Isfahan Shir, Namfar, Mohandesieh, Ghyam, Ghohab, Rafieyan, FudeSepahan, Lavark, and FKA for their valuable support and unreserved assistance.

\section{References}

[1] Morrill, K.M., Conrad, E., Lago, A., Campbell, J., Quigley, J. and Tyler, H. (2012) Nationwide Evaluation of Quality and Composition of Colostrum on Dairy Farms in the United States. Journal of Dairy Science, 95, 3997-4005.

https://doi.org/10.3168/jds.2011-5174

[2] Guy, M.A., McFadden, T.B., Cockrell, D.C. and Besser, T.E. (1994) Effects of Unilateral Prepartum Milking On concentrations of Immunoglobulin G1 and Prolactin in Colostrum. Journal of Dairy Science, 77, 3584-3591.

https://doi.org/10.3168/jds.S0022-0302(94)77302-1

[3] Pritchett, L.C., Gay, C.C., Besser, T.E. and Hancock, D. (1991) Management and Production Factors Influencing Immunoglobulin G1 Concentration in Colostrum 
from Holstein Cows. Journal of Dairy Science, 74, 2336-2341. https://doi.org/10.3168/jds.S0022-0302(91)78406-3

[4] Gulliksen, S.M., Lie, K.I., Sølverød, L. and Østera, O. (2008) Risk Factors Associated with Colostrum Quality in Norwegian Dairy Cows. Journal of Dairy Science, 91, 704-712. https://doi.org/10.3168/jds.2007-0450

[5] Conneely, M.D., Berry, P., Sayers, R., Murphy, J.P., Lorenz, I., Doherty, M.L. and Kennedy, E. (2013) Factors Associated with the Concentration of Immunoglobulin $\mathrm{G}$ in the Colostrum of Dairy Cows. Animal, 7, 1824-1832. https://doi.org/10.1017/S1751731113001444

[6] Quigley, J.D., Martin, K.R., Dowlen, H.H., Wallis, L.B. and Lamar, K. (1994) Immunoglobulin Concentration, Specific Gravity, and Nitrogen Fractions of Colostrum from Jersey Cattle. Journal of Dairy Science, 77, 264-269.

https://doi.org/10.3168/jds.S0022-0302(94)76950-2

[7] Mellado, M., Lopez, E., Veliz, F.G., De Santiago, M.A., Macias-Cru, U., Avenda-o-Reyes, L. and Garcia, J.E. (2013) Factors Associated with Neonatal Dairy Calf Mortality in a Hot-Arid Environment. Livestock Science, 159, 149-155. https://doi.org/10.1016/j.livsci.2013.11.019

[8] Morin, D.E., McCoy, G.C. and Hurley, W.L. (2001) Effects of Quality, Quantity, and Timing of Colostrum Feeding and Addition of a Dried Colostrum Supplement on Immunoglobulin G1 Absorption in Holstein Bull Calves. Journal of Dairy Science, 80, 747-753. https://doi.org/10.3168/jds.S0022-0302(97)75994-0

[9] Nardone, A., Lacetera, N., Bernabucci, U. and Ronchi, B. (1997) Composition of Colostrum from Dairy Heifers Exposed to High Air Temperatures during Late Pregnancy and the Early Postpartum Period. Journal of Dairy Science, 80, 838-844. https://doi.org/10.3168/jds.S0022-0302(97)76005-3

[10] Fishwick, G. and Clifford, D. (1975) The Effects of Low Protein Intake by Beef Cows during Pregnancy on the Voluntary Intake of Roughage, the Composition of the Colostrum and Serum Immunoglobulin Concentration of Their Calves. Proceedings of the Nutrition Society, 34, 74A.

[11] Olson, D.P., Bull, R.C., Woodard, L.F. and Kelley, K.W. (1981) Effect of Maternal Nutritional Restriction and Cold Stress on Young Calves' Absorption of Colostral Immunoglobulins. American Journal of Veterinary Research, 42, 876-880.

[12] Baumrucker, C.R., Burkett, A.M., Magliaro-Macrina, A.L. and Dechow, C.D. (2010) Colostrogenesis: Mass Transfer of Immunoglobulin G1 into Colostrums. Journal of Dairy Science, 93, 3031-3038. https://doi.org/10.3168/jds.2009-2963

[13] Kitson, R.E. and Mellon, M. G. (1944) Colorimetric Determination of Phosphorus as Molybdic-Vanadophosphoric Acid. Industrial and Engineering Chemistry, Analytical Edition, 16, 379. https://doi.org/10.1021/i560130a017

[14] Association of Official Analytical Chemists (1990) Official Methods of Analysis. AOAC, Washington DC.

[15] SAS Institute (2003) SAS User's Guide. Version 9.1. Edition. SAS Institute, Cary.

[16] Kehoe, S.I., Jayarao, B.M. and Heinrichs, A.J. (2007) A Survey of Bovine Colostrum Composition and Colostrum Management Practices on Pennsylvania Dairy Farms. Journal of Dairy Science, 90, 4108-4116. https://doi.org/10.3168/jds.2007-0040

[17] Kruse, V. (1970) The Chemical Composition of Colostrum and the Absorption of Immunoglobulins in New-Born Calves. Proceeding 18th International Dairy Congress, $1,681$.

[18] Foley, J.A. and Otterby, D.E. (1978) Availability, Storage, Treatment, Composition, and Feeding Value of Surplus Colostrum: A Review. Journal of Dairy Science, 61, 
1033-1060. https://doi.org/10.3168/jds.S0022-0302(78)83686-8

[19] Levieux, D. (1999) Colostrum, a Milk Particularly Rich in Numerous Components. Is It Possible to Detect Its Unlawful Addition in Milk Supplies? Milk, 79, 465-488.

[20] Herr, M., Bostedt, H. and Failing, K. (2011) IgG and IgM Levels in Dairy Cows during the Periparturient Period. Theriogenology, 75, 377-385. https://doi.org/10.1016/j.theriogenology.2010.09.009

[21] Carstens, G.E., Johnson, D.E., Holland, M.D. and Odde, K.G. (1987) Effects of Prepartum Protein Nutrition and Birth Weight on Basal Metabolism in Bovine Neonates. Animal, 65, 745-751.

[22] Nowak, W., Mikula, R., Zachwieja, A., Paczynska, K., Pecka, E., Drzazga, K. and Slosarz, P. (2012) The Impact of Cow Nutrition in the Dry Period on Colostrum Quality and Immune Status of Calves. Polish Journal of Veterinary Science, 15, 77-82. https://doi.org/10.2478/v10181-011-0117-5

[23] Lona-D, V. and Romero-R, C. (2001) Short Communication: Low Levels of Colostral Immunoglobulin in Some Dairy Cows with Placental Retention. Journal of Dairy Science, 84, 389-391. https://doi.org/10.3168/jds.S0022-0302(01)74488-8

[24] Rausch, W.D., Hofer, A., Gemeiner, M. and Möstl, E. (1989) Catecholamine and Cortisol Concentrations in Plasma from Cattle at Parturition. Journal of Veterinary Medicine, 36, 218-224. https://doi.org/10.1111/j.1439-0442.1989.tb00722.x

[25] Muller, L.D. and Ellinger, D.K. (1981) Colostral Immunoglobulin Concentrations among Breeds of Dairy Cattle. Journal of Dairy Science, 64, 1727-1730. https://doi.org/10.3168/jds.S0022-0302(81)82754-3

[26] Oyeniyi, O.O., and Hunter, A.G. (1978) Colostral Constituents Including Immunoglobulins in the First Three Milkings Postpartum. Journal of Dairy Science, 61, 44-48. https://doi.org/10.3168/jds.S0022-0302(78)83549-8

[27] Devery-Pocius, J.E. and Larson, B.L. (1983) Age and Previous Lactations as Factors in the Amount of Bovine Colostral Immunoglobulins. Journal of Dairy Science, 66, 221-226. https://doi.org/10.3168/jds.S0022-0302(83)81780-9

[28] Kume, S. and Tanabe, S. (1993) Effect of Parity of Holstein Cows on Vitamin A and Beta-Carotene Concentrations of Colostrums and Calf Serum. Animal Science Technology, 64, 987-991.

[29] Romo, G.A., Kellems, R.O., Powell, K. and Wallentine, M.V. (1991) Some Blood Minerals and Hormones in Cows Fed Variable Mineral Levels and Ionic Balance. Journal of Dairy Science, 74, 3068. https://doi.org/10.3168/jds.S0022-0302(91)78492-0

[30] Gay, C.C., McGuire, T.C. and Parrish, S.M. (1983) Seasonal Variation in Passive Transfer of Immunoglobulin G1 to Newborn Calves. Journal of the American Veterinary Medical Association, 183, 566-568. 
Submit or recommend next manuscript to SCIRP and we will provide best service for you:

Accepting pre-submission inquiries through Email, Facebook, LinkedIn, Twitter, etc. A wide selection of journals (inclusive of 9 subjects, more than 200 journals)

Providing 24-hour high-quality service

User-friendly online submission system

Fair and swift peer-review system

Efficient typesetting and proofreading procedure

Display of the result of downloads and visits, as well as the number of cited articles Maximum dissemination of your research work

Submit your manuscript at: http://papersubmission.scirp.org/

Orcontact as@scirp.org 